Meta

Journal des traducteurs

Translators' Journal

\title{
Strategy to Block Interference from the Source Language (cognate signifiants) in Korean-Chinese Interpretation
}

\author{
Hye-Rim Kim
}

Volume 51, numéro 2, juin 2006

Théories et pratiques de la traduction et de l'interprétation en Corée Theories and Practices of Translation and Interpretation in Korea

URI : https://id.erudit.org/iderudit/013254ar

DOI : https://doi.org/10.7202/013254ar

Aller au sommaire du numéro

Éditeur(s)

Les Presses de l'Université de Montréal

ISSN

0026-0452 (imprimé)

1492-1421 (numérique)

Découvrir la revue

Citer cet article

Kim, H.-R. (2006). Strategy to Block Interference from the Source Language (cognate signifiants) in Korean-Chinese Interpretation. Meta, 51(2), 247-262. https://doi.org/10.7202/013254ar

\section{Résumé de l'article}

Bien que le coréen et le chinois ne fassent pas partie de la même famille linguistique, ils ont un dénominateur commun, qu'on peut appeler des «signifiants isotopiques ». Cela signifie que ces deux langues peuvent s'écrire et se prononcer de la même manière et que ces ressemblances visuelles et phonétiques peuvent exercer une grande influence sur le processus d'interprétation.

L'objectif de notre travail est de montrer l'influence de ces « signifiants isotopiques ", qui provoquent en général une interférence linguistique nuisible à l'extraction du sens, et de réfléchir sur les améliorations que l'on pourrait apporter à la méthodologie interprétative, et ceci à travers l'analyse des différents exemples d'interprétation du coréen vers le chinois.

Nous avons pu analyser plusieurs exemples d'interprétation incorrecte due à une interférence de ces "signifiants isotopiques ", ainsi que mettre en avant et étudier divers types d'interférence ; au vu du résultat de cette analyse, nous avons pu élaborer un mécanisme de blocage, qui serait susceptible de réduire efficacement l'influence des « signifiants isotopiques ».
Ce document est protégé par la loi sur le droit d'auteur. L'utilisation des services d'Érudit (y compris la reproduction) est assujettie à sa politique d'utilisation que vous pouvez consulter en ligne.

https://apropos.erudit.org/fr/usagers/politique-dutilisation/ 


\title{
Strategy to Block Interference from the Source Language (cognate signifiants) in Korean-Chinese Interpretation
}

\author{
HYE-RIM KIM \\ Ewha Womans University, Seoul, Korea \\ hyerim@ewha.ac.kr
}

\section{RÉSUMÉ}

Bien que le coréen et le chinois ne fassent pas partie de la même famille linguistique, ils ont un dénominateur commun, qu'on peut appeler des «signifiants isotopiques». Cela signifie que ces deux langues peuvent s'écrire et se prononcer de la même manière et que ces ressemblances visuelles et phonétiques peuvent exercer une grande influence sur le processus d'interprétation.

L'objectif de notre travail est de montrer l'influence de ces «signifiants isotopiques», qui provoquent en général une interférence linguistique nuisible à l'extraction du sens, et de réfléchir sur les améliorations que l'on pourrait apporter à la méthodologie interprétative, et ceci à travers l'analyse des différents exemples d'interprétation du coréen vers le chinois.

Nous avons pu analyser plusieurs exemples d'interprétation incorrecte due à une interférence de ces «signifiants isotopiques», ainsi que mettre en avant et étudier divers types d'interférence; au vu du résultat de cette analyse, nous avons pu élaborer un mécanisme de blocage, qui serait susceptible de réduire efficacement l'influence des «signifiants isotopiques ».

\section{ABSTRACT}

Although Korean and Chinese are not from the same family of languages, they have the common denominator of cognate signifiant that is, both languages can be written with the same methods of expression. In this case cognate signifiant means that both Korean and Chinese can be expressed in Chinese characters. There are many similarities in the visual and acoustic images of the two languages and for this reason cognate signifiant persistently intervenes in interpretation of one to the other.

Therefore, the purpose of this study is to highlight through the analysis of case studies how cognate signifiant causes interference by hindering the extraction of meaning in Korean-Chinese interpretation, and to explore ways of increasing Korean-Chinese interpretation ability based on the results of such research.

In order to approach this issue, recorded examples of incorrect interpretation resulting from interference caused by cognate signifiant will be analyzed from the perspective of interpretation studies, which places importance on the conveyance of meaning for the purpose of achieving communication. Based on the results of such research, strategies to effectively block interference resulting from cognate signifiant will be established.

\section{초록}

한국어와 중국어는 동족언어로 분류되지는 않지만 ‘동원기표소'를 사용한다는 점 에서 공통분모를 갖고 있다. 동원기표소는 동일 漢字로 표기가 가능하며 두 언어 사이에서 시각적, 청각적 이미지의 유사성을 띠고 있기 때문에 두 언어간 통역 과 정에 적극적으로 개입하고 있다.

따라서 본 연구는 한↔중 통역에 있어서 의미추출을 방해하여 언어간섭을 야기하 는 同源記票素의 영향을 사례 분석을 통해 조명하고 이를 토대로 한 $\leftrightarrow$ 중 통역능 력 향상을 위한 방법 모색에 목적을 둔다. 
본 연구를 통해 동원기표소에 의한 간섭으로 잘못된 통역을 낳고 있는 예들을 대 상으로 간섭유형에 대한 분석이 이루어지고, 분석 결과를 토대로 동원기표소에 의 한 간섭을 효과적으로 차단하기 위한 간섭차단기제가 수립되었다.

\section{MOTS-CLÉS/KEYWORDS}

cognate signifiant, interference-blocking model, designification, faux amis, collocation

\section{Introduction}

The two basic types of interpretation used today are consecutive interpretation and simultaneous interpretation. Consecutive interpretation refers to the method in which the interpreter listens to the speaker, takes note of the contents, and when the speaker pauses, directly conveys the speech in the first person as if making the speech him/ herself. (Choi 1999: 25-30)

In contrast, simultaneous interpretation refers to the method in which the interpreter sits in a booth listening to the speaker through headphones and, through a microphone, almost simultaneously interprets the contents of the speech in a language that the audience can understand. Consecutive interpretation is somewhat different in that the interpreter extracts the proper information from notes and from memory, and produces a linguistically correct and culturally appropriate target text, monitoring his/her interpretation at the same time.

In the course of simultaneous interpretation, the process of listening to and understanding the source language, and then expressing the contents in the target language takes place in a matter of seconds or split seconds. And even as the interpreter is producing the target language text, he/she must continue to comprehend the source language that is streaming through the headphones. Lee Tae-hyeong (1999) proved through machine analysis that in the case of English-Korean simultaneous interpretation, the interpreter handles listening and speaking simultaneously during more than 60 percent of the speech.

Certainly, while the interpreter is speaking, his/her ability to listen and express is affected because speaking and listening are occurring at the same time. Because the information processing ability of the human brain is limited, the interpreter bears a substantial cognitive burden when listening and speaking take place simultaneously.

Therefore, Kim Dae-jin (2002: 21) analyzed that compared to consecutive interpretation, simultaneous interpretation is, by nature, apt to be surface-oriented rather than content-oriented in many cases, and sometimes remains at the level of word-forword translation. With the source language continuing to come into the interpreter's awareness at the same time he/she is speaking in the target language, surface-oriented interpretation is the understandable result. In this case, the interpreter is seriously affected by linguistic interference from the source language, in contrast to the interference from the native language which occurs in second-language learning.

[Original text] 최근 몇 년 사이에 한국과 중국은 심각한 황사문제를 격었습니 다. 서울뿐만 아니라 북경에서도 심각한 황사피해에 시달렸습니다.

[choegeun myeot nyeon saie hangukgwa junggukeun simgakhan hwangsamunjereul kyeo eotsseomnida. seoulppunman anira buk-gyeongeseodo simgakhan hwangsapihaee sidallyeotsseomnida.] 
[English translation] In the past few years, Korea and China have experienced serious problems with yellow sand. Not only Seoul, but also Beijing has suffered serious damage from yellow sand.

\section{[Simultaneous interpretation]}

最近几年当中，韩国跟中国有了非常严重的黄沙问题，不只是汉城，北京也有非 常严重的黄沙、沙尘暴问题。

[zuijin jinian dangzhong, hanguo gen zhongguo youle feichang yanzhongde huangsha wenti, buzhishi hancheng, beijing yeyou feichang yanzhongde huangsha, shachenbaowenti.]

In the Korean language, "hwangsa (황사)," known as yellow sand, refers to a meteorological condition in which dust or fine sand floats in the air. But in the Chinese language, "huangsha (黄沙)" literally refers to "sand that is yellow," or "material that can be bought at a sand shop."

Here the interpreter knew that the Chinese word "huangsha (黄沙)" and the Korean word "hwangsa (황사)" did not have the same meaning. But in the course of simultaneous interpretation, the instant the interpreter perceived "hwangsa (황사)" in the source language he/she produced the expression "huangsha (黄沙) sand that is yellow)" in the target language. At that moment, the interpreter realized through monitoring of interpretation contents that he/she had used the wrong term, and from the second mention of “huangsha (黄沙)" the interpreter corrected the utterance to “yellow sand (沙尘暴).”

It could be assumed that this phenomenon occurred, first, because the interpreter had insufficient understanding of the original text and incorrectly grasped the sense of the Korean word "hwangsa (황사)," and, second, because he/she did not know the exact expression in the target language, and thus, transliterated "hwangsa (황사)" into Chinese characters and "borrowed" the Chinese pronunciation.

However, considering that the interpreter corrects the utterance from "sand that is yellow (黄沙)” to “yellow sand (沙尘暴), it is correct to regard this phenomenon as the result of interference from the source language in the course of simultaneous interpretation, which is carried out under severe time limitations, rather than as an error of understanding or expression.

The primary cause for such interference from the source language may be that in simultaneous interpretation, cognitive processing must take place in an instant, but the fundamental cause can be found in the fact that the Korean language and the Chinese language share cognate signifiants ${ }^{4}$ (i.e., cognate Chinese characters).

In the above example, both the Korean word "황사 [xuansa]" and the Chinese word “黄沙 [xuansa]” are made up of the cognate signifiants “黄” and “沙,” and the existence of cognate signifiants confirms that they persistently intervene in simultaneous interpretation of one language to the other. Given this finding, the purposes of this study are to examine the role of cognate signifiants in Korean-Chinese interpretation and explore ways to handle them, and thereby to explore effective methods of training to block interference from the source language.

\section{Cognate Signifiant}

Because signifie is the mental "sense" for expressing the signifie, a carrier of the sense is needed. Here, this carrier of sense is called the signifiant. The signifiant is the "sign 
image" and can be largely divided into the acoustic (sound) image and the visual image (Kim 2002: 23). Both images are physical forms of the sign. The visual image is understood as what can be seen and drawn. For instance, in the case of characters, the printed characters can be seen and read out loud.

Cognate signifiants refers to all characters that can be written with Chinese characters. In the Korean language, all characters are cognate signifiants, except for those that form uniquely Korean words (those that have been newly created and cannot be written with Chinese characters). In the Chinese language all characters can be called cognate signifiants.

Korea and China are neighboring countries located in Northeast Asia, and both cultural communities use Chinese characters as a means of writing. ${ }^{5}$

Indeed, in ancient times the Chinese writing system was introduced in Korea and its use was firmly established. At that time, because early Koreans did not have a writing system of their own, they seemed to have accepted Chinese characters along with other aspects of the Chinese culture. Thus, the spoken language and written language came to be used as bilingual systems with mutually distinctive forms. In the past, spoken language and written language were likely to have influenced each other, but it is easy to surmise that the influence of written language was much greater than that of spoken language. In this way, elements of Chinese characters began to penetrate the Korean language system, forming the linguistic and cultural system found in modern Korean language.

Chinese character words, ${ }^{6}$ which account for over 60 percent of the Korean vocabulary, consist of more than one cognate signifiant as a basic unit. The existence of these cognate signifiants that constitute Chinese words can be found in the Chinese character system, with the exception of Chinese characters newly created in Korea. ${ }^{7}$

Of course, these cognate signifiants have different visual and acoustic images within each language system. That is, both the characters and sounds are different. For example, let's compare two words, the Chinese word “学校” and the Korean word “학교." When both words are written in Chinese characters, both become “學校." “學校” is composed of two cognate signifiants, “學” and “校.”

But “學” and “校” are perceived as different images in each language system. The visual and acoustic images of the cognate signifiants “學” and “校” in the Chinese word “学校” are [学][校] and [cye] [ciau], respectively, but the visual and acoustic images of cognate signifiants “學” and “校” in the Korean word “학교” are [학][교] and $\left[\right.$ hak' $\left.^{\prime}\right][\mathrm{kjo}]$, respectively. ${ }^{9}$

But in these different images there is "similarity" and the "possibility of analogy," which is possible because the cognate signifiants originate from Chinese characters. "Similarity" is related to "sound." Since it was assimilated in Korea the ancient sound of the Chinese language has changed more or less according to the unique linguistic customs of Korea, and as a living language the Chinese characters have undergone a certain amount of change in the Korean language system over a long period of time. But because the two languages are rooted in the sound of Chinese characters, there is similarity in their acoustic images.

Also, anyone who knows both Chinese and Korean languages can analogize the cognate signifiants of the words, whether Chinese or Korean words, and can also see what images such analogized cognate signifiants have in each language system. 
As a specific example, anyone who sees or hears the character '수' would be able, at the very least, to call to mind such cognate signifiants as 수(手), 수(水), 수(秀), 수(壽), 수(綬), 수(需), 수(隨), 수(數), 수(繡), 수(首), and 수(囚).

The visible image of the Korean character '수' is [수] and its acoustic image is [su]. Visible and acoustic images of the Chinese characters which can be analogically inferred from the Korean character '수' are as follows:

TABLE 1

\begin{tabular}{|c|c|c|c|c|c|c|c|c|c|c|}
\hline Cognate signifiant & 手 & 水 & 秀 & 壽 & 綬 & 需 & 隨 & 繡 & 首 & 贝 \\
\hline Visual image & 手 & 水 & 秀 & 寿 & 绶 & 需 & 随 & 绣 & 首 & 贝 \\
\hline Acoustic image & sou & șuei & ciou & sou & sou & $6 y$ & suei & ciou & sou & tc'iou \\
\hline
\end{tabular}

Table 1 shows that acoustic images have a certain regularity as they all begin with [s], [c], $[\mathrm{s}]$, or $\left[\mathrm{t}_{c^{\prime}}\right]$. Also, these acoustic images are similar to the Korean consonant $[\mathrm{s}]$.

In the case of the two-syllable word “입장," “입장(入場)” (entrance) and “입장 (立場)” (position) come to mind, and the cognate signifiants “入,” “場,” and “立” can be analogized. In this case, the visible and acoustic images in the Korean language are [입][장] and [ip'] [can], respectively, and the visible and acoustic images in the Chinese language are [入], [立], [场] and [ru], [li], [tcian], respectively. Here, the similarity between [r] [1] and [i], [can] and [tcian] can also be perceived.

If the interpreter encounters the Chinese word “梦想," he/she will instantly recall the cognate signifiants “夢” and “想” that is, the word “夢想” (reverie). Likewise, similarity can be found between the acoustic images [məy] and [mon], and [cian] and [say] in each language system.

As shown above, there is a possibility of analogy in the different images of each language and similarity between the acoustic images in each language system. It is called "sound similarity," that is, "paronym," in this study.

Such sound similarity and "possibility of analogy" of cognate signifiants persistently intervene in Korean-Chinese interpretation and are manifested as interference from the source language. Interference caused by cognate signifiants does not just occur at the lexical level but is also likely to occur at all levels, ranging from morphemes to words, sentences, and text.

\section{Cases of Interference Caused by Cognate Signifiants}

Simultaneous interpretation is a multi-tasking process in which the interpreter expresses a unit of meaning in the target language and at the same time grasps the sense of new words perceived by the brain. Also, the interpreter's grasp of the sense, that is, understanding of meaning, should keep pace with the speed of the speaker's utterances. In addition, a simultaneous interpreter carries the burden of listening to the speaker's speech and his/her own voice at the same time. This burden reduces the efficiency of listening and has an adverse effect on recognition of the source language and expression of the target language. Kim Dae-jin (2002: 99) points out that although this phenomenon becomes more serious when the target language of interpretation is not the interpreter's native language but the " $\mathrm{B}$ " language, or foreign language, it occurs all the same when the target language is the " $\mathrm{A}$ " language, or the interpreter's native language. 
[Original text] 但是他的助手中, 聚集了一批亲台反华的共和党右翼势力。 [danshi zai tade zhushouzhong, jujile yipi qintaifanhuade gonghedeng youyishili.]

[Simultaneous interpretation] 그의 조수 중에는 친대만 반중국 성향의 우익세력 이 포진해있다. [gui-ui josu jung-eneun chindaeman banjungguk seonghyangui uikseryeoki pojinhaeitda.]

[English translation] Among his assistants, many are right-wing forces with pro-Taiwan and anti-China leanings.

The Chinese word “zhushou (助手)" literally means “a person who is at one's side to assist," so it can be used in the Korean language to mean "aide" or "working-level staff." But the Korean word "josu (조수)" has the disparaging connotation of a trainee learning technical skills. Therefore, its meaning is limited to "a person who assists a technician."

“josu 조수” and “zhushou 助手” are faux amis ${ }^{10}$ in the two languages. Although the Korean language and the Chinese language do not have the same linguistic roots there are a great number of words composed of the identical combination of cognate signifiants but with different signifie. As a result, interference caused by cognate signifiants is frequently found in interpretation.

[Original text] 선거에서 온갖 불법 및 부정선거에 개입했다. [seongeo-eseo ongat bulbeop mit bujeongseonge-e gaeiphaetda.]

[English translation] All kinds of illegal and corrupt behavior were involved in the campaign.

[Simultaneous interpretation] 在选举期间，介入了各种非法及不公正的行为。 ${ }^{11}$ [zai xuanju qijian, jierule gezhong feifa ji bugongzhengde xingwei.]

“All kinds of illegal and corrupt behavior were involved” is interpreted as “介入 了各种非法及不公正的行为” but this is an inappropriate expression in the Chinese language, because the combination of "jieru (介入)" and "gezhong feifa ji bugongzhengde xingwei (各种非法及不公正的行为)” does not correspond to Chinese language collocation.

Collocation $^{12}$ explains the syntagmatic relation or chain relationship of lexical items and refers to lexical relations that are customarily used together. Collocation has a huge impact on "expression," particularly on reformulation in the target language, so it is a factor directly related to accuracy, clarity and naturalness of interpreted text.

Such violations of collocation are often found in Korean-Chinese interpretation.

[Original text]... 유엔총회를 1국 1표라는 보편적 통합주의에 근거해 구성하되... [yuenchonghoereul ilguk ilpyoraneun bopyeonjeok tonghapjuuie geungeohae guseonghadoe ]

[English translation]... United Nations General Assembly formed on the basis of the rule of universal unity, one country one vote...

[Simultaneous interpretation]...根据一国一票的普遍整合主义组成了联合国总会... ${ }^{13}$ [genju yiguoyipiaode pubianzhenghezhuyi zuchengle lianheguozonghui ] 
While "yuenchonghoe유엔총회(總會)" conforms to the linguistic customs of the Korean language, “lianhegudahui 联合国大会(大會)” is a customary Chineselanguage expression. Ignoring this custom and borrowing the expression of the source language in the form of simple replacement makes understanding difficult for the listener or interferes with the accuracy of the message.

The above-mentioned examples all result from interference caused by borrowing cognate signifiants as they are in the source language text. Now let us take a look at a type of interference that occurs in the form of "explanation of meaning," not simple borrowing.

[Original text] 中国现代化建设起点很低, 还处于初始阶段。

[zhongguo xiandaihuajianshe qidian hendi, haichuyu chushijieduan.]

[Simultaneous interpretation] 중국의 현대화건설은 기점이 매우 낮아 아직 시작 단계에 머물러 있다. ${ }^{14}$

[junggukui hyeondaehwageonseoleun gijeomi maeu nat-ja ajik sijakdangye-e meomulleo itda.]

[English translation] The starting point of China's modernization construction is very low and still remains at the initial stage.

“gi 기(起)”and “jeom점(點)”are from the original text and are borrowed in the target language text, and “hen很” and “di低” are interpreted in the form of “explanation of meaning." But the expression "the starting point of China's modernization construction is so low" is difficult to understand immediately. The Chinese word “qidian 起点” means “start line” and here connotes the meaning of “start." Therefore, interpreting the predicate "di 低" as "late" rather than "low" is not only more effective in conveying meaning but is also an appropriate expression of the target language.

As seen above, in simultaneous interpretation there are cases in which word-forword translation results in the failure to "convey the meaning." This happens as a result of prior knowledge of cognate signifiants, which interferes with the interpreter's ability to catch the sense and then produce the target language. Therefore, it can be seen that the existence of cognate signifiants is the fundamental cause for source language-interference in Korean-Chinese interpretation.

\section{Strategy to Block Interference from the Cognate Signifiant}

\subsection{Interference Blocking Model}

In Korean-Chinese interpretation, all interpreters, regardless of their skill, suffer from interference caused by cognate signifiants, and there is also a high probability of interference. Therefore, it is important to build a cognate signifiant interference-blocking model in order to prevent source language cognate signifiants from interfering.

Interpretation is catching the sense from the source language text through "understanding" of the text and conversion of the sense to the target language text. ${ }^{15}$ The purpose of interpretation is to achieve communication. In other words, interpretation is a process of catching the sense and re-expressing that sense in the target language.

But given the characteristics of languages, it is very important in Korean-Chinese interpretation, to deal with cognate signifiants, a common denominator of the two 
languages. This is directly related to the production of equivalent language and a precondition for catching the sense.

Therefore, in order to minimize interference, a strategy to effectively guard against cognate signifiants is needed. That is, an effective strategy is needed to block borrowing of cognate signifiants in a similar form, without destroying the physical form (i.e. signifiant) in Korean-Chinese interpretation.

The Korean-Chinese interpretation process model should be explained in two steps: one is to catch the sense from the source language text through designification, and the other is to re-express the sense in a form appropriate to the target language text. Accordingly, a cognate signifiant interference blocking model can be established as seen in Figure 1.

FIGURE 1

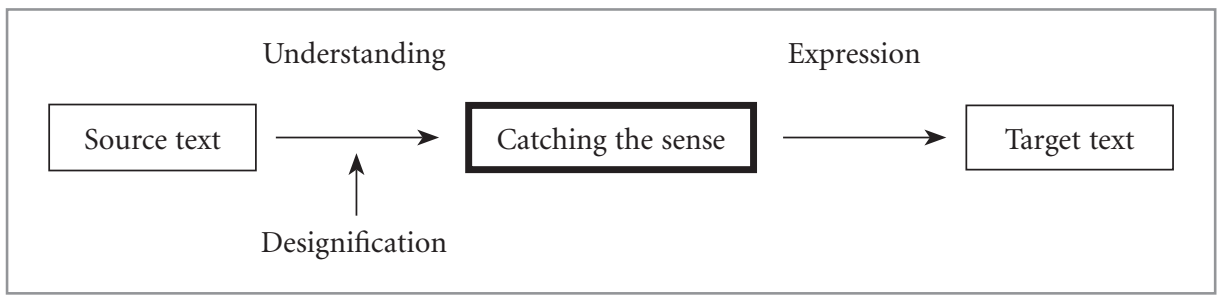

In the cognate signifiant interference blocking model, catching the sense through designification is very important, because it is through this process that the target for translation, the sense, can be grasped.

The sense caught through designification is re-expressed by using the target language. Here, an appropriate expression that conforms to the language system of the target language should be used. The figure for this process is as follows:

FIGURE 2

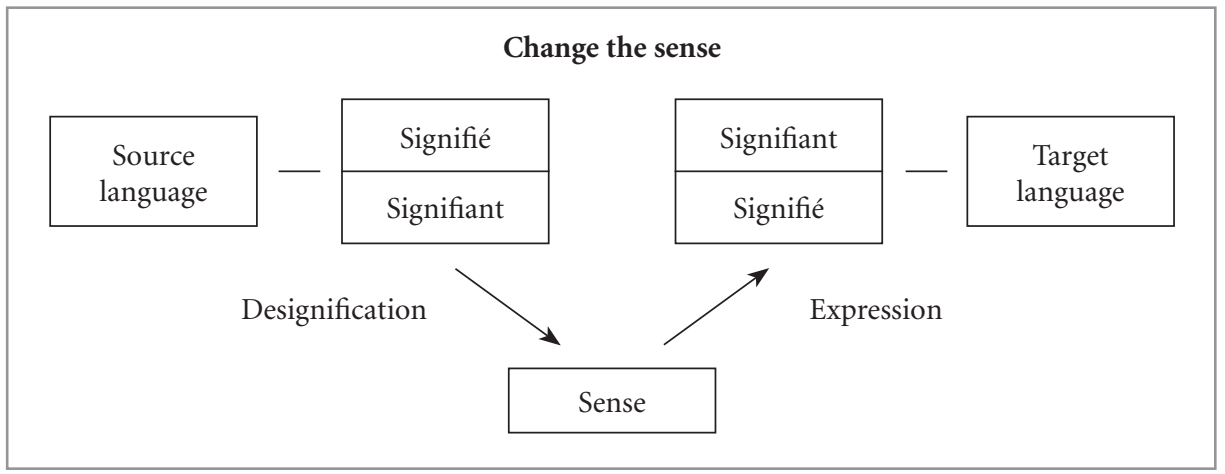

The process of interpretation between Chinese and Korean, which have the common denominator of cognate signifiants, calls for catching the sense through designification and then, on the basis of that sense, selecting a signifiant in the target language system. Only when interpretation is carried out in this way will interference arising from cognate signifiants be reduced and successful communication achieved. 
The key to this interference blocking model is catching the sense through designification. Here designification means looking beyond the form of the signifiant in the source language and correct understanding of what the word containing that signifiant means in the text. Therefore in this interference blocking model, catching the sense is the basic strategy for blocking language interference. From this, and from the fact that it is the intermediate stage between understanding and expression, it can be easily understood how important catching the sense is in the process of interpretation.

When there is failure to catch the sense, the interpreter generally chooses the method of transposing sentence for sentence and word for word; and in this process cognate signifiants easily interfere.

Catching the sense is a cognitive process that we all know. As the sensory data disappears it becomes knowledge in a form that cannot be perceived. In this way, information that has gone beyond the form of language from the text settles in the mind of the interpreter. Regarding this, Delisle ${ }^{16}$ concludes that, "Once the sense has been understood the reformulation is carried out not on the basis of individual words but what has been thought."

According to study results on Think-Aloud Protocols, ${ }^{17}$ an experimental method tested in the 1980s out of interest in the process of translation rather than the results, errors in translation arising from incorrect analysis of the text or in the course of expression in the target language originate in failure to fully catch the sense. The study results prove just how important it is to break away from the linguistic signs that arise at the same time as understanding of cognitive and definitive meaning, or in other words, they show just how important the process of designification is for successful translation and interpretation.

For example, in order to increase interpreting ability by blocking interference arising from cognate signifiants in Korean-Chinese interpretation, it is necessary to completely catch the sense. If this is the case, then how is catching the sense successfully achieved?

Seleskovitch (1994: 91) said that while the young interpreter must consciously strive to resist linguistic interference, this effort becomes second nature to the experienced interpreter. Ultimately, it can be said that the more skilled the interpreter, the more automatized interference blocking becomes, enabling smooth interpreting. This is a skill that can be gained through continuous training. In this paper the following methods of training are suggested in order to establish the interference blocking model.

\subsection{Training Methods}

Interpretation ability is closely related to the development of language ability, communication ability and cognitive ability. Therefore, this paper suggests methods of training for blocking interference from cognate signifiants from the perspectives of language ability, communication ability and cognitive ability.

\subsubsection{Language Ability Perspective}

Simultaneous interpretation is a multi-tasking process in which the utterance of the speaker must be understood and the sense caught. Then, what has been understood must be uttered in the target language, while at the same time the new utterance of the speaker must be understood. Here the time available is hardly adequate to express 
the content as understood in the target language in the most appropriate way, that is, to express it in the form most appropriate ${ }^{18}$ for the listener to hear and understand instantly. Almost instantaneous decision and action must go together.

Therefore, the interpreter must shorten as much as possible the time he/she takes to overcome interference from the source text and find the appropriate vocabulary in the target language. The best way for an interpreter to do this is to expand his/her vocabulary. Given the severe time limitations of simultaneous interpretation, the interpreter has no time for on-the-spot analysis and decisions. Rather, he/she should be able to access expressions already stored in the memory, and use them. Moreover, this vocabulary must be stored at a level ${ }^{19}$ at which it can be used instantly.

Language information that is stored in the memory for instant retrieval reduces the interpreter's cognitive processing load and helps increase intuition in expressing the target language.

Lee Tae-hyeong (1999) suggests that for simultaneous interpretation, which is a multi-tasking process, it is very important to reduce the burden of thinking up new expressions. In order to do this he states that a rich store of strategic language expressions must be inputted, specifically, that memorization of specialized terminology and diverse expressions is necessary, and that through expansion of information storage in the long-term memory, limited information processing capability can be invested in other tasks such as conversion and utterance.

According to scholars of psycholinguistics, ${ }^{20}$ in the process of human cognitive processing the working memory is distinguished from the traditional concept of short-term memory ${ }^{21}$; it is explained as a concept connoting more dynamic perspective in the memory process. That is, the working memory has the functions of storage and processing, but because the resources of the working memory are limited, storage and processing are in inverse proportions.

Considering this stage of cognitive processing, the simultaneous interpreter at work in the booth goes through the cognitive processes of understanding and expressing, as well as analyzing and synthesizing across languages. Therefore, the hypothesis can be made that the greater the interpreter's basic knowledge ${ }^{22}$ the greater the processing function for analysis and synthesis, and in reverse, the less the interpreter's basic knowledge the less the processing function for analysis and synthesis.

In the cognition model that explains the process of human information processing, human beings, after recognizing information, pass it through the working memory and the short-term memory and finally store it in the long-term memory. In this model the ultimate purpose of the short-term memory is to store information in the long-term memory or to hear and then forget information according to the judgment of the central processing device.

However, simultaneous interpretation requires the processing of information in another language after the information is received. Therefore, it is to the interpreter's advantage to memorize basic vocabulary in order to reduce the cognitive burden on the working memory and the short-term memory.

Paraphrasing is a specific way to help increase vocabulary. Kim Dae-jin (2003) introduces paraphrasing as an effective way to establish concepts and explains that through this interpretation intuition and predictability can be increased.

If an interpreter has been trained in paraphrasing in Chinese and Korean, which have in common cognate signifiants, in order to increase vocabulary, and has therefore 
been exposed through such training to diverse forms of expression to express the same sense, then there is greater probability that he/she will select a different expression rather than resort to simple borrowing. Therefore, the interpreter who automatizes the method of selecting a different form of expression to that of the source text through repeated paraphrase training will have the advantage when it comes to using expressions in the target language that are less similar to the signifiant form of the vocabulary as it appears in the source language.

\subsubsection{Communication Ability Perspective}

Interpretation is an activity with the ultimate goal of communication. Therefore, the interpreter plays the mediating role in conveying to the listeners what the speaker wants to say. In order to accomplish this, the interpreter must first understand the content of the speaker's utterance; that is, the interpreter must understand the "sense." And to ensure that the listeners also grasp the "sense," the interpretation must be in an easily understood form. Therefore, it can be said that communication ability is determined by the ability of the interpreter to catch the sense, and convey that sense.

Sense is only one aspect of interpretation. Considering that most international conferences currently focus on very specialized themes, the communication ability required of an international conference interpreter can also be summarized as the ability to catch information and convey information.

The purpose of technical texts is the transmission of information. Therefore, to achieve successful communication in the interpretation of technical texts the interpreter is required to have sufficient knowledge of the subject in order to understand the information. Maodun ${ }^{23}$ emphasized early on that language proficiency is only the minimal condition for interpretation and that the interpreter must have both specialized knowledge and a wealth of knowledge aside from language knowledge. Lederer (2001: 29) also said that in the case of technical texts, the more specialized the interpreter the better he/she is able to understand the text.

Because sufficient expansion of specialized knowledge in the end facilitates empathy with the speaker and helps to instantly convey the speaker's utterance, satisfactory deciphering of information in the source-language text can lead to successfully catching the sense. Just as a person uses language as a tool to express thoughts, the sense can also be expressed in the target language. Then the interpreter is not selecting and synthesizing words from the vocabulary of the target language that correspond to the individual words used in expression of the source language; rather the thoughts already inside the interpreter's head are being expressed in his/her own language.

Therefore, the better able the interpreter is to achieve smooth and successful information deciphering, the less the chance of interference arising from the source text.

\subsubsection{Cognitive Ability Perspective}

Simultaneous interpretation is carried out through a complex cognitive process that requires multi-tasking. It calls for understanding of the source text and expression of the text in the target language; monitoring and correction of the interpreter's own utterances; and the power of observation to catch the various kinds of clues inherent in the interpreting situation. ${ }^{24}$ In the process of such multi-tasking, the key is none other than "catching the sense." If the sense has not been caught, it is impossible to express the sense in the target language. 
Thus, as interpretation is the task of first understanding something oneself in order to make others understand, the interpreter who is not able to grasp the sense commonly resorts to word-for-word translation. With this method, however, the interpreter is not able to make the listener understand, and as such it is difficult to expect proper communication.

If this is the case, it is necessary to consider how the sense is caught. The interpreter takes the series of words that come into the ear and condenses them into sense at intervals of a few seconds, and, as a result, the sense of the words (language knowledge) and the cognitive supplements (knowledge other than language knowledge) are synthesized as one to form a unit of meaning. ${ }^{25}$

Such a unit of meaning has no fixed length and understanding of this unit of meaning does not come at uniform points in the continued utterances of the speaker. Therefore it is impossible to produce any concrete data regarding how long after the speaker has started the utterance; that is, at what point should the interpreter turn the utterance into the target language. The time lag will probably be different for each language and there will be differences according to the individual interpreter's method of interpretation and interpretation strategies. Nevertheless, following too close on the heels of the speaker's utterance should be avoided.

At the stage of understanding the source text, that is, at the listening stage, if interpretation is carried out too soon after the speaker's utterance there is the danger of falling into parroting. With parroting, there is a high probability that the interpreter will select similar words that come easily to mind, or will opt for word-for-word correspondence, and in that process, interference from cognate signifiants becomes more active.

In teaching simultaneous interpretation, it can be confirmed that the student who follows too closely after the speaker is easily exposed to interference from the source text, and as a result, the student's expression in the target language is not only very unstable, he/she also has inaccurate understanding of the content of the speaker's utterance. In other words, rather than correctly grasping the content and interpreting on the basis of what has been understood, the student rushes into parroting.

From the moment the interpreter borrows the cognate signifiant from the source text, he/she falls into the danger of simple transposition in the understanding stage. In simple transposition, or parroting, interference from cognate signifiants becomes more active.

Accordingly, simultaneous interpretation requires a time lag in which the unit of meaning can be grasped. In such a case, from the second unit of meaning, understanding and expression occur at the same time. Ultimately, at the same time as the first unit of meaning is expressed the new unit of meaning is remembered in the brain of the interpreter, not in the form of separate words but as a cluster of "sense."

Seleskovitch (1994: 28-31) pointed out that the interpreter does not remember words, only their sense and for this reason it is impossible to carry out simultaneous interpretation through word-for-word transposition.

In addition to simultaneous interpretation following units of meaning, another useful method of training is to automatize in the whole cognitive process the strategy of first selecting the signifiant as far removed from the cognate signifiant as possible, in order to reformulate the meaning in the target language.

According to Seleskovitch (1994: 91), experienced interpreters will often choose not to use the easy equivalent of the word he/she hears in the source language, even 
when this would be perfectly correct; instead they choose a word that is phonologically and semantically as different as possible from the original word.

This gives an idea of the strategies used by skilled interpreters to block interference from the source language. That is, instead of the primary words associated with the source vocabulary in terms of signifie or phonology in the target language expression, they choose the vocabulary that is most rarely associated in terms of signifie or phonology.

In the process of Korean-Chinese interpretation, if the technique of first selecting the signifiant that is farthest from the acoustic image of the cognate signifiant that comes to the ear is automatized, then the possibility of interference from cognate signifiants can be greatly reduced.

In the case of a talented interpreter, multi-tasking is mostly automatized. In fact, study results have shown that deliberately concentrating on one task among several leads to reduced accuracy in interpretation rather than improving interpretation quality. ${ }^{26}$

For example, in order to become a talented interpreter one must disperse attention not deliberately but automatically and such cognitive ability must be increased through continued and repeated training.

Accordingly, in simultaneous interpretation based on units of meaning, it is important to continuously practise methods such as selection of a dissimilar signifiant first and through this kind of training the interference-blocking model becomes automatized, ultimately leading to increased cognitive ability.

\section{Conclusion}

Simultaneous interpretation is a multi-tasking process in which a speaker's words continuously ring in the interpreter's ears, while at the same time the sense of those words must be caught and then uttered in the target language. In these unique circumstances the interpreter receives interference from the source language.

The two languages of Korean and Chinese, both springing from cultures that use Chinese characters, share in common cognate signifiants. Through analysis of the results of Korean-Chinese interpretation, this paper has shown that the fundamental cause of interference from the source language is the existence of these cognate signifiants. In addition, to block interference from cognate signifiants, it suggests an interferenceblocking model (Fig. 3) based on catching the sense through designification.

The concrete methods of training suggested in this paper need to be studied further to test their efficacy through post-application and verification. This should be accompanied by efforts to develop more effective and diverse training methods. In this respect, the participation of and exchange of views by many scholars is anticipated. 


\section{FIGURE 3}

\section{Interference blocking model}

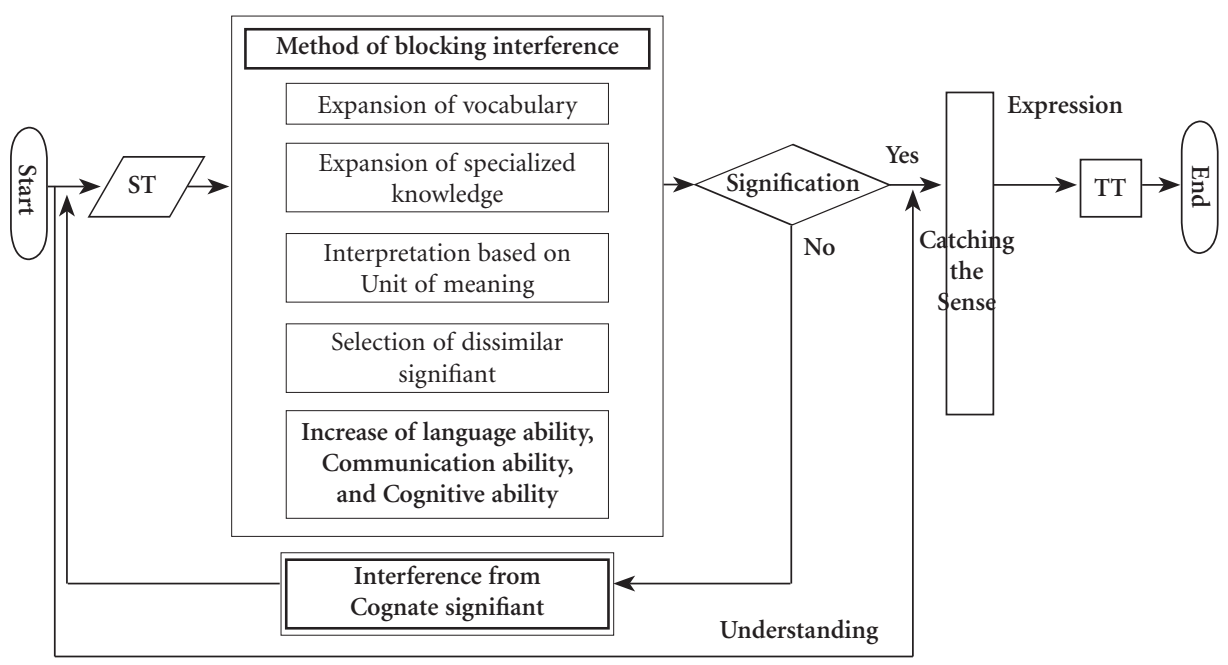

\section{NOTES}

1. According to Chinese meteorological data, yellow sand is differentiated as "floating dust (浮尘)," “blowing sand (扬沙), " and “sand or dust storm (沙尘暴)." “Floating dust” refers to the condition in which dust or fine sand floats in the air when there is either no wind or a weak wind and visibility is about 10 kilometers. "Blowing sand" refers to the condition in which relatively strong winds sweep up sand from the ground, turning the atmosphere turbid, and visibility is 1-10 kilometers. The term "sand or dust storm" refers to the condition in which strong winds sweep up masses of sand from the ground, turning the atmosphere very turbid, and visibility is less than 1 kilometer. Strictly speaking, the Korean word "hwangsa" corresponds to all three categories.

2. See Dong-a Ilbo April 8, 2003.

3. Transliteration is a type of borrowing in which the Korean word is visually transliterated into Chinese characters and acoustically pronounced according to the Chinese sound system (Meng 2003).

4. Refer to this paper (2. Cognate Signifiant).

5. When they had no writing systems of their own, Korea and Japan borrowed Chinese characters, and used them in their respective written languages. Later, when the Korean alphabet, Hangeul, was created, the language could be expressed through Hangeul alone or in combination with Chinese characters. In Japan, however, Chinese characters are still necessary as a means of writing along with Japanese characters.

6. "Words based on Chinese characters from China" (Korean Language Dictionary 1997: 3663).

7. Because they are limited to several words such as 垈, 媤, 欌, and 沓, almost all components of Chinese-character words can be considered cognate signifiants.

8. Koreans continue to write traditional Chinese characters in the same way as they were first introduced, while the mainland Chinese have used simplified Chinese characters since the People's Republic of China government publicly announced the common simplified form in 1952, following the new government's reformation of the writing system in 1949. This study uses traditional Chinese characters in writing the cognate signifiants that appear in the description, except for examples.

9. The written form of acoustic images in this study follows the writing principle of the International Phonetic Alphabet. See Lin and Wang (1999), Kim Seung-gon (1983).

10. Faux amis are French words meaning "false friends." Michel Ballard defined the two terms as "signs in two different languages, two terms that have homonymic and paronymic relations but slightly different meanings.” J.P. Vinay and J. Darbelnet (2003: 63).

11. This part can be interpreted as “在选举期间, 犯下了各种非法及不公正的行为.” 
12. According to Terminology Dictionary for Korean Language and Linguistics (1995: 557-558), collocation refers to what should be memorized as one group without enunciating each word, one by one, in order for more than two words to be connected and used as a unit. Collocation is related to customary lexical use in a language system.

13. “...根据一国一票的普遍整合主义组织了联合国大会...”

14. “The start of China's modernization construction was so late that it still remains at an initial stage."

15. According to interpretative theory, interpretation consists of the steps of understanding, deverbalization, and re-expression. Interpretative theory, which emphasizes the importance of interpreting the sense, explains that "interpretation" or understanding of the sense is reached after passing through the stage of deverbalization, which means going beneath the linguistic surface to catch the sense.

16. Lederer (2001: 34).

17. "Think-Aloud Protocols" are a method of observing the cognitive processes of the translator during the translation process. Jean Delisle, Hannelore Lee-Jahnke (2002: 192-193).

18. Seleskovitch (1994: 120) uses the term "intelligibility" for the level of expression allowing listeners to instantly understand upon hearing. In translation the term "readability" is used for the same concept.

19. This refers to a level where it can be applied almost reflexively even within severe time limitations, and means that vocabulary should be memorized in such a way (active, not passive) that it can be reproduced at any time.

20. David W. Carroll (1999: 47-50).

21. The general approach to the cognitive process is to summarize it as recognition of information that is finally stored in the long-term memory after passing through the working memory and the shortterm memory.

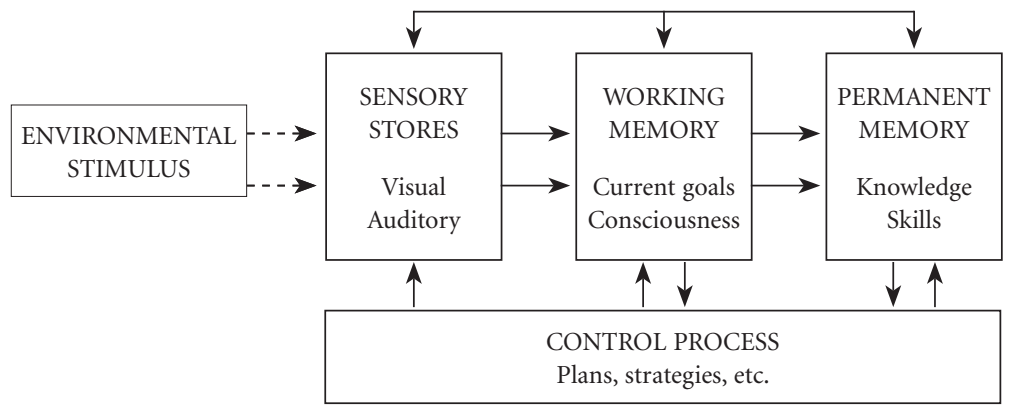

22. Here basic knowledge refers to the translator's language knowledge and knowledge other than language knowledge.

23. Peng (2000: 125).

24. This includes following the presentation materials, checking the listener's response to the speaker's gestures etc.

25. Refer to Lederer (2001: 17-19). The unit of meaning, as the smallest factor that enables equivalence in translation, changes into deverbalized knowledge as it is synthesized into one consistent thought.

26. See Kim, Dae-jin (2003).

\section{REFERENCES}

Carroll, D. W. (1999): Psychology of Language, Brooks/Cole Publishing Company.

CHOI, J. (2001): Interpretation, Translation Know-how, Nexus.

Chor, J. (1999): Becoming an International Conference Interpreter, Korean Media Resources Materials Publishing Association.

Delisle, J. and H. Lee-Jahnke (Eds), translated by Kim, Jong-gyu, Kim, Jeong-yeon (2002): Translation Terminology, Korea University Press.

Eunpyeong Research Institute (Editor) (1997): Korean Language Dictionary, Geumseong Publishing Company. 
KIM, G. (2002): What is Semiology?, Mineumsa.

KIM, D. (2002): Teaching Interpretation for International Conferences. Hanguk Munhwasa

KIM, D. (2003): "Study of Training Methods for Interpretation through the Cognitive Process of Interpretation and Understanding Dual-language Mastery," International Conference Interpretation and Translation 5-2, p. 53-78.

Kiм, S. (1983): Phonetics, Jeongeumsa.

Kim, Y. (1983): “Determining the Translation Process and Related Problems," Linguistics 6, The Linguistic Society of Korea.

KIM, J. (1998): Korean Lexical Theory, Tap Publishing Company.

Kıм, H. (1998): Translation Studies, Mineumsa.

KIM, H. (2001): "Linguistic Interference Arising from Chinese Character Words in Korean-Chinese Interpretation," International Conference Interpretation and Translation 3.

Kim, H. (2003): "A Study of Cultures Using Chinese Characters and their Impact on Translation Studies," Forum 1.

Kim, H. (2003): "Study of Interference Caused by Cognate Signifiants in Korean-Chinese Translation," Hankuk University of Foreign Studies, Chinese Language Department, Ph.D. dissertation.

LeE, Y. (1974): Study of Korean Chinese-Character Words, Samyeongsa.

LeE, E. (1995): Dictionary of Korean Language and Linguistics Terminology. Gukeomunhwasa.

LeE, T. (1999): "Study of Pauses in Korean-English Simultaneous Interpretation," International Conference Interpretation and Translation 1.

LeE, T. (2002): "Computer Analysis Tools for the Time Aspect of Simultaneous Interpretation," International Conference Interpretation and Translation 4-2.

Lee, T. (2003): "English Listening and Interpretation Training Following the Form of Korean Subtitle Translation," International Conference Interpretation and Translation 5-2, p. 127147.

Lin, T., Wang, L., Lee, H. and S. Sim (Eds) (1999): Chinese Phonetics, Gyoyuk Gwahaksa.

Lederer, M., translated by Jeon, Seong-gi (2001): Translation - The Interpretive Model, Korea University Press.

MA, Z. (1984): A History of Chinese Translation Studies, Zhongguoduiwaifanyichubangongsi.

Meng, J.(2003): “Translation of Chinese Linguistic Terminology," Chinese Language Research 17. Peng, Z. (2000): Translation Studies, Beijingtushuguanchubanshe.

Seleskovitch, D., translated by Stephanie Dailey, Eric Norman McMillan (1994): Interpreting for International Conferences, Pen and Booth.

Seleskovitch, D., translated by Jeong, Ho-jeong (2002): Interpreting for International Conferences, Hanguk Munhwasa.

Sнiм, J. (1998): Trends in Korean Linguistic Studies, Taehaksa.

Venuti, L. (Ed) (1999): The Translation Studies Reader, London and New York.

VinaY, J.P. and J. Darbelnet, translated by Jeon Seong-gi (2003): Comparative Stylistics of French and English: A Methodology for Translation, Korea University Press.

WiLss, W., translated by Lee Gi-seok, Kim, Gap-nyeon (2002): Translating and Interpreting in the $21^{\text {st }}$ Century, Korea University Press.

Zноu, J. (1998): Lexical Theory, Tianjingujichubanshe. 